\title{
HUBUNGAN PERSEPSI DUKUNGAN ORANG TUA DENGAN PENGUASAAN KOSAKATA ANAK USIA 6-7 TAHUN
}

\author{
Zahrina Amelia \\ Program studi Pendidikan Guru Pendidikan Anak Usia Dini \\ Fakultas Psikologi dan Pendidikan \\ Universitas Al Azhar Indonesia \\ J1.Sisingamangaraja Kebayoran Baru, Jakarta Selatan 12110, Indonesia
}

\begin{abstract}
This correlational research aims to see the relation of perception of parent support to the mastery of vocabulary 6-7 years old in South Jakarta. The research method used is correlational research, with the subject of this study a South Jakarta, with a sample 120 children. Research carried outby the technique of collecting the datathrough the survey with the help of a questionnaire. Mastery of the vocabulary of children covers vocabulary (1) active-productive that use the word, and (2) passivereceptive that understand the meaning of the word. Perception of the Support Parents are the views of children on assistance or support social were given a parent to a child, includes (1) support the emotional, (2) support informational, (3) instrumental. The Data analysis technique in this research is quantitative data analysis. Results Show that there is a significant correlation between perception of parent support with vocabulary mastery with coefficient value of determination $71 \%$. These results imply that there is a relationship of perception of parent support and social ability to vocabulary mastery.
\end{abstract}

Keywords: perception of parent support, vocabulary mastery, correlational research 
Abstrak--- Penelitian korelasional ini bertujuan untuk melihat hubungan persepsi dukungan orangtua sosial terhadap penguasaan kosakata usia 6-7 tahun di Wilayah Jakarta Selatan. Metode penelitian yang digunakan adalah penelitian korelasional, dengan subjek penelitian ini di wilayah Jakarta Selatan dengan sampel 120 anak. Penelitian dilakukan dengan teknik pengumpulan data melalui teknik survey dengan bantuan kuisioner. Penguasaan kosakata anak mencangkup kosakata (1) aktif-produktif yaitu menggunakan kata, dan (2) pasif-reseptif yaitu memahami makna kata. Persepsi terhadap Dukungan Orangtua adalah pandangan anak pada bantuan atau dukungan sosial yang diberikan orangtua kepada anak, meliputi (1) dukungan emosional, (2) dukungan informational, (3) instrumental.Teknik analisis data dalam penelitan ini adalah analisis data kuantitatif. Hasil Menunjukkan bahwa terdapat hubungan signifikan antara persepsi dukungan orangtua dengan penguasaan kosakata dengan nilai koefisien determinasi 71\%, Hasil tersebut memberikan implikasi bahwa terdapat hubungan persepsi dukungan orangtua terhadap penguasaan kosakata.

Kata kunci: persepsi dukungan orangtua, penguasaan kosakata, penelitian korelasional.

\section{PENDAHULUAN}

Perkembangan seorang anak dapat dilihat dari beberapa aspek perkembangan seperti perkembangan bahasa, kognitif, sosial emosional, motorik kasar dan motorik halus anak. Salah satu perkembangan anak yaitu perkembangan bahasanya yang ditunjukan melalui potensi yang dimiliki pada diri anak yang perlu dikembangkan sejak dini.

Pada saat berkomunikasi dengan orang lain yang dibutuhkan pada anak yaitu penguasaan kosakata yang dimilikinya. Menurut hasil penelitian Roulstone dkk, Departement for Children menjelaskan bahwa pentingnya mendukung bahasa anak dan komunikasi pada anak sejak sedini mungkin. Anak pada usia awal perkembangannya saat ini mengalami penurunan penguasaan pada saat berkomunikasi dengan orang lain. Anak sering kali salah menafsirkan apa yang dikatakan oleh orang lain. Anak yang mengalami kesulitan berkomunikasi dengan orang lain 
salah satunya dipengaruhi dari perkembangan bahasa anak yang akan berbanding lurus dengan penguasaan kosakata yang dimiliknya.

Kenyataannya salah satu faktor anak mengalami kesulitan dalam berkomunikasi ialah kurangnya penguasaan anak terhadap kosakatanya. Saat ini anak lebih sering bermain dengan gadget dibandingkan berinteraksi dengan orang lain. Berdasarkan NCCA dalam French mengatakan Kelompok tertentu dari populasi berusia usia 3 tahun rata-rata anak mengetahui dituntut memahami 900-1000 kata, tetapi baru memahami baru memahaminya sekitar 500 kata, dan pada usia 6 tahun rata-rata anak mengetahui dituntut memahami 20.000 kata, tetapi baru memahami baru memahaminya sekitar 2600 kata. Rendahnya kosa-kata yang dimiliki anak akan berpengaruh pada komunikasi yang dijalin dengan orang lain. Apabila hal tersebut terjadi anak akan terhambat dan dapat menghambat pula interaksi sosialnya. Agar dapat menjalin interaksi sosial yang merupakan hubungan antara anak dengan orang lain, mereka dituntut untuk memiliki kemampuan sosial.

Penelitian yang sudah diuraikan sebelumnya dapat didukung dengan penelitian Eileen. Rodriguez, dalam penelitian Parent's Role in Fostering Young Children's Learning and Language Development menjelaskan bahwa intervensi dan pencegahan harus memperhatikan beberapa aspek perkembangan dan pengembangan dalam belajar. Di dalamnya berisi dukungan orangtua dalam memberikan kegiatan yang medukung bahasanya dan memberikan berbagai fasilitas belajar. Melalui dukungan yang diberikan anak dari rumah secara bertahun-tahun akan mendukung pertumbuhan bahasa dan belajarnya.

Pada penelitian yang telah dilakukan sebelumnya lebih fokus pada perkembangan anak, intervensi lingkungan, komunikasi anak dan belum memfokuskan pada penguasaan kosakata anak, dukungan orangtua dan kemampuan sosial anak. Fakta di lapangan saat ini anak lebih sering berinteraksi dengan media elektronik dibandingkan dengan berkomunikasi dan berinteraksi dengan teman sebayanya. Hal ini dapat dilihat penguasaan kosakata anak dituntut memahami 15.000-20.000 kata, sedangkan pada kenyataanya saat ini anak usia 6 tahun baru memahami sekitar 5.000 kata. Hal tersebut terjadi karena saat ini orangtua lebih fokus pada pekerjaannya dan hanya memilki sedikit waktu untuk berinteraksi dengan anaknya. Bedasarkan penelitian relevan dan fakta dilapangan, penelitan ini penting dilakukan dalam rangka 
menggambarkan bagaimana hubungan persepsi dukungan orangtua dan kemampuan sosial anak terhadap penguasaan kosakata anak di sekolah dasar kelas 1.

\section{A. Penguasaan Kosakata}

\section{Pengertian Penguasaan Kosakata}

Penguasaan kosa kata seorang anak berkaitan erat dengan pemahaman terhadap pengetahuan yang dimilikinya. Suatu penguasaan berkaitan dengan pemahaman yang berarti, tidak hanya mengingat atau pun menghafal sesuatu namun juga mampu untuk mengungkapkan kembali apa yang diketahuinya dengan kata-kata sendiri yang lebih mudah dimengerti. Pemahaman mengenai pengetahuan yang dimiliki oleh anak akan memberikan rasa puas karena anak merasa berhasil terhadap apa yang dipelajarinya. Martell mengatakan bahwa "mastery is the sense of accomplishment experienced, and pleasure is the feeling of enjoyment that accompanies an activity". Pengertian di atas dapat diartikan penguasaan adalah rasa keberhasilan yang dialami, dan kesenangan yang merupakan perasaan kenikmatan yang menyertai suatu kegiatan.

Jalongo mengatakan "vocabulary consists of the word we must know in order to communicate effectively". Pengertian di atas dapat diartikan yaitu, kosakata terdiri dari katakata yang harus dimengerti oleh seseorang dalam berkomunikasi secara efektif. Anak menggunakan kosakata untuk berkomunikasi dengan orang lain. Hal itu dapat menjelaskan bahwa melalui kosa kata, akan memudahkan anak dalam menerima informasi, mengemukakan idenya, berinteraksi dan berkomunikasi dengan orang lain serta kemampuan sosial yang baik.

Dari beberapa pakar yang telah dikemukakan di atas dapat sintesiskan bahwa penguasaan kosa kata merupakan kemampuan yang berkaitan dengan pemahaman dalam suatu bidang tertentu dan kemampuan menunjukan untuk melakukan sesuatu. Penguasaan tersebut berkaitan dengan pemahaman yang berarti tidak hanya mengingat atau menghafal sesuatu, tetapi pemahaman juga mampu untuk mengungkapkan kembali apa yang dipahaminya dalam bentuk yang berbeda dengan menggunakan kata-katanya sendiri yang 
mudah dipahaminya. Apabila anak memiliki penguasaan kosakata yang cukup, maka anak akan memiliki kemampuan sosial yang baik.

\section{Karakteristik Penguasaan Kosa Kata 6-7 Tahun}

Saat anak memasuki dunia sekolah, kosakata yang dimiliki akan bertambah dengan cepat. Anak bertemu dengan teman-teman sebayanya, dan juga orang banyak yang berada di lingkungan yang lebih luas. Lingkungan luar rumah dapat memberikan pengalaman baru kepada anak, sehingga kosakata anak dapat bertambah luas. Kosakata yang dimiliki oleh anak berusia enam sampai dengan tujuh tahun tidak terlepas dari pengalaman berbahasanya pada usia sebelumnya. Melzi dan Ely mengungkapkan bahwa, " there is also evidence that children who begin the primary years with a larger vocabulary will continue to experience greater vocabulary growth than children who enter the primary years with a more limited vocabulary." Uraian tersebut memiliki arti yaitu, penguasaan kosakata yang dimiliki oleh anak pada tahun pertama, akan terus mengalami perkembangan kosakata yang lebih besar dibandingkan dengan anak yang pada tahun pertamakosakatanya terbatas.

Jumlah kata dan pemahaman kata yang dimiliki oleh anak pada setiap tingkatan kelas, jelas berbeda. Guntur mengungkapkan, tata bahasa menjelang dewasa, yaitu pada usia 6-8 tahun dimana pada usia ini ditandai dengan kemampuan yang mampu menggabungkan kalimat sederhana dan kalimat kompleks. Uraian tersebut memperjelas bahwa, saat usia anak 6-7 tahun anak telah memiliki penguasaan kosakata yang cukup besar karena pada tahap usia ini anak telah mampu untuk menggabungkan kalimat sederhana dan kalimat kompleks yang dimana membutuhkankatakata untuk dapat menjadi kalimat.

Dari beberapa pendapat pakar yang telah dikemukakan sebelumnya maka dapat jelaskan karakteristik anak usia 6-7 tahun merupakan usia peralihan dari prasekolah ke sekolah dasar. Anak pada usia tersebut memiliki pembendaharaan kata sekitar 15.00020.000 kata, anak dapat membuat kalimat yang lebih sempurna, dapat membuat kalimat majemuk, dan dapat menyusun dan mengajukan pertanyaan. 
Berdasarkan beberapa pendapat pakar yang telah dijelaskan sebelumnya, maka dapat disintesiskan bahwa Penguasaan kosakata anak adalah kemampuan pada anak dalam memahami dan dapat mengutarakan kata-kata yang ingin disampaikan. Penguasaan kosakata anak mencangkup kosakata (1) aktif-produktif yaitu menggunakan kata, dan (2) pasif-reseptif yaitu memahami makna kata.

Pasif-reseptif yaitu memahami makna kata yang meliputi kemampuan anak untuk menggunakan kalimat dengan baik dan benar saat berkomunikasi, kemampuan anak menggunakan kata kerja, benda, dan sifat dalam komunikasi lisan, kemampuan anak menceritakan suatu peristiwa yang diketuinya scara terstruktur, kemampuan anak mamahami kata-kata yang diterimanya baik lisan maupun tulisan, kemampuan anak memberikan tanggapan dangan informasi yang diberikan, dan kemampuan anak membedakan kata kerja, benda, sifat. Aktif-produktif yaitu kemampuan menggunakan kata-kata.

\section{B. Persepsi Dukungan Orangtua}

\section{Persepsi}

Dapat dikatakan persepsi seseorang bersifat kompleks yang menyebabkan orang dapat menerima informasi yang diperoleh dari lingkungannya, pada anak yaitu lingkungan keluarganya. Setiap orang memiliki pandangan atau persepsi yang berbeda-beda dengan apa yang dilihatnya. Sehubungan dengan hal tersebut dikemukakan oleh Slameto bahwa persepsi adalah proses masuknya pesan atau informasi ke dalam otak manusia. Melalui persepsi manusia terus menerus mengadakan hubungan dengan lingkungan yang dilakukan melalui indera, yaitu penglihatan, pendengaran, perasa atau penciuman. Fungsi tersebut terletak pada proses pemberian makna atau arti terhadap sensasi yang diterimanya.

Pada dasarnya persepsi seperti yang dikemukakan di atas melalui berbagai definisi adalah kegiatan mental seseorang yang berlangsung diawali dengan adanya kontak indera dengan lingkungannya sehingga diperoleh informasi yang berarti setelah melalui peoses pengolahan dalam otak manusia berupa tanggapan-tanggapan, diinterpretasikan pada 
pengalaman. Persepsi sebagi proses psikologi yang mengasilkan kemampuan kognisi yang berupa pengalaman.

Oleh sebab itu persepsi merupakan pengalaman sebagai hasil menyimpulkan dan menafsirkan objek atau peristiwa. Melalui persepsi manusia terus mengadakan hubungan dengan lingkungannya. Hubungan tersebut dilakukan melalui proses penginderaan, dengan adanya persepsi manusia dapat berinteraksi dan memberi kesan atau arti terhadap apa yang dialaminya. Dapat dikatakan persepsi yaitu pemberian makna atau arti pada lingkungan, benda atau peristiwa. Dalam penelitian ini persepsi secara khusus dibatasi pada persepsi anak terhadap dukungan orangtua dan akan dibahas lingkup dukungan orang tua terhadap anaknya yaitu melalui pengalaman-pengalaman yang diberikan orangtua kepada anak.

Adapun persepsi anak adalah suatu proses aktif yang melibatkan diri dengan perseptornya. Persepsi anak berhubungan erat dengan rangsangan-rangsangan spasial seperti perilaku orangtua atau sesuatu yang berupa sentuhan, gerakan, ekspresi dan perasaan. Oleh karena itu pemahaman, pengamatan maupun tanggapan anak terhadap perilaku orangtua melalui berbagai perlaku orangtua.

Berdasarkan beberapa uraian yang telah dikemukakan di atas, maka dapat disintesiskan persepsi ialah pandangan individu yang diperoleh sebagai hasil dari pengalaman dan belajar, proses menerima, mengorganisasikan dan menafsirkan makna dari informasi yang ditangkap oleh indera sehingga menghasilkan suatu pengertian yang berarti bagi individu.

2. Pengertian Dukungan Orangtua

Setiap orang jika diberikan bantuan berupa rasa nyaman, senang dan menghargai sesuatu akan membuat orang lain merasakan dirinya diperhatikan, serta meningkatkan rasa percaya diri. Dukungan yang diberikan pada seseorang akan mampu untuk melakukan sesuatu atau memecahkan permasalahan sehari-hari sehinga dapat dijadikan pengalaman. Rietschlin dalam Taylor megatakan bahwa:

"Sosial support is defined as information from others that one is love and care for, esteemed and valued, abd part of network of communication and mutual obligations. Social upport can come from parent, a spouse or lover, other relatives, friends, social and community contacts". 
Berdasarkan kutipan di atas dukungan sosial dapat didefinisikan sebagai informasi atau bantuan dari orang lain bahwa seseorang dicintai dan dirawat, terhormat dan dihargai, dan bagian dari hubungan jaringan komunikasi dan kewajiban bersama.

Dukungan sosial dapat diperoleh dari orangtua, pasangan, kerabat lain, teman-teman, masyarakat dan orang yang terdapat kontak sosial. Pada anak dukungan sosial dapat diperoleh dari keluarga, yaitu orangtuanya. Dapat dikatakan sebuah dukungan sosial apabila antara anak dan orangtua memiliki hubungan interaksi.

Lingkungan disekitar anak yang saling berkaitan antara satu dengan yang lainnya dapat mencerminkan perlaku yang terdapat dilingkungannya, seperti yang dikemukakan Thomson yaitu "sosial support is inherently a reciprocal procsess, accuring in socially constructed networks close relationship (exp. Intimates, family, significant others, and friends)." Dukungan sosial pada dasarnya dapat diartikan sebagai proses timbal baik seseorang dibangun dalam suatu jaringan sosial yang memiliki hubungan dekat seperti keluarga, orang lain yang memiliki hubungan dekat). Proses interaksi tersebut terjadi dalam dukungan sosial yang dibangun dekat seperti keluarga, lingkungan sekolah (guru), dan teman-temanya. Hubungan sosial yang baik dengan lingkungannya terdekat dapat mengembangkan kemampuan verbal dan non verbal seorang anak.

Dari beberapa pendapat pakar yang telah dikemukakan dapat disimpulkan dukungan sosial yaitu bantuan yang diberikan orangtua melalui interaksi dan komunikasi yang dilakukan secara verbal dan non verbal yang dilakukan oleh orang-orang terdekat dalam memberikan perhatian, kepedulian, penghargaan, memberikan informasi, dan pengajaran dalam kehidupan anak untuk bekal anak dalam kehidupan dimasa yang akan datang.

3. Jenis-jenis Dukungan Orangtua

Dukungan orangtua yang diperoleh anak dapat berupa pemberian kepedulian, kenyamanan, memberikan contoh/modeling atau dapat berupa penghargaan atas tugas yang telah dicapainya dapat berupa penguatan agar mampu mengerjakan tugasnya dengan baik, dukungan tersebut dapat dikatakan sebagai dukungan sosial orangtua. 
Pada anak dukungan sosial sangat diperlukan untuk menunjang kemapuan yang dimilikinya, terdapat jenis-jenis dukungan sosial menurut Chiou dalam Arthur menjelaskan bahwa

"Based on fungtional approaches categorizes social support into five aspect; (1) material; instrumental support, assistance; (2) emotional; affective support, value view point, understanding; (4) informational advice, cognitive support, guidance; (5) companionate; positive sosial interaction”.

Dari pendapat di atas dapat dijelaskan berdasarkan pendekatan fungsional dalam mengkategorikan dukungan sosial yaitu; (1) dukungan materi; dukungan instrumental, bantuan, (2) emosional; dukungan afektif, peduli/ perhatian, ekspresi, (3) rasa penghargaan/ hormat; tegas, dukungan nilai sudut pandang, pemahaman, (4) informasi; saran, dukungan kognitif/pengetahuan, bimbingan, (5) companionate, interaksi sosial yang positif.

\section{METODE}

\section{Partisipan}

Penelitian ini akan dilakukan di wilayah Jakarta Selatan, Kecamatan Pesanggrahan. Populasi dalam penelitian ini adalah anak yang sedang mengikuti program pendidikan anak usia dini kelompok B dikecamatan kebayoran lama yaitu sebanyak 5.132 anak. Dalam penelitian ini, sampel yang diambil dari kelurahan. Kelurahan yang dapat pada tenik pengambilan sampel yaitu kelurahan Pesanggaran. Dengan demikian jumlah sampel minimal dalam penelitian ini sebanyak 98 orang dan mengantisipasi adanya kendala, maka jumlah sampel diambil dilebihkan minimal sebanyak 10\%. Agar sampel menjadi representatif maka jumlah sampel dilebihkan menjadi 168 orang.

\section{Desain}

Metode peneltian ini menggunakan teknik survey dengan teknik korelasi. Kelinger dalam ridwan mengatakan bahwa "penelitian survei merupakan kegiatan yang dilakukan pada populasi 
bersar ataupun kecil, tetapi data yang dipelajari adalah data dari sampel yang diambil dari populasi tersebut. Penelitan ini termasuk pada peneltian korelasional dengan menggunakan pendekatan kuantitatif. Teknik ini digunakan statistik sebagai alat untuk analisis seperti koefisien korelasi untuk menguji hubungan dua variabel atau lebih variabel untuk dapat menarik kesimpulan umum (generalisasi) berkenaan dengan hubungan antara variabel tersebut.

Adapun uji validitas yang dilakukan terhadap instrumen kemampuan komunikasi dilakukan dengan menguji validitas konstruk dan validitas empiris. Uji validitas konstruk dilakukan melalui uji pakar (expert judgment) oleh ahli dalam bidangnya.

Setelah melalui uji pakar dan mendapatkan data hasil uji coba, untuk mengetahui apakah setiap butir dalam instrumen tersebut valid atau tidak maka akan dilakukan uji validitas menggunakan korelasi product moment, yaitu dengan membandingkan nilai $\mathrm{r}_{\text {hitung }}$ dengan nilai $\mathrm{r}_{\text {tabel }}\left(\mathrm{r}_{\text {kritis }}\right.$ ). Sedangkan untuk uji reliabilitas instrumen menggunakan rumus Alpha Cronbach.

\section{Teknik Analisis}

Data dalam penelitian ini akan dianalisis secara statistic deskriptif dengan mengolah data awal untuk mencari rata-rata atau mean, median, modus, simpangan baku, nilai maksimum dan nilai minimum. Semua data tersebut disajikan secara deskriptif melalui distribusi frekuensi, baik dengan menggunakan tabel maupun grafik histogram. Serta dianalisis secara statistik inferensial yang dipergunakan sebagai alat dalam rangka mencoba menarik suatu kesimpulan yang bersifat umum maupun bersifat khusus dari sekumpulan data yang telah diolah. Statistik inferensial terdiri dari beberapa tahapan proses pengujuan yaitu ; Uji normalitas, uji homogenitas. Untuk membantu perhitungan menggunakan teknik SPPS.

ANALISIS DAN HASIL

\section{A. Penguasaan Kosakata}

Variabel penguasaan kosakata diukur menggunakan instrumen angket dan observasi, yang terdiri dari 17 butir setelah dilakukan uji coba instrumen. Data tersebut kemudian diolah 
menggunakan metode statistik akan menunjukkan hasil secara analisis deskriptif. Analisis tersebut digunakan agar melihat gambaran data pada masing-masing variabel yang dinyatakan melalui mean, median, modus, dan simpangan baku dalam bentuk tabel dan histogram. Banyaknya kelas di hitung menurut aturan Struges, diperoleh 7 kelas dan panjang tiap kelas yaitu 7, dengan nilai skor maksimum 68 dan skor minimum 20 sehingga rentang skor 48.

Berdasarkan hasil perhitungan statistic deskriptif diperoleh instrumen penguasaan kosakata mempunyai nilai rata-rata(mean) sebesar 48,78 dengan median sebesar 48,5, modus 51 sebesar, dan standar deviasi 11,87 Pengelompokan data dapat dilihat pada tabel distribusi frekuensi tersebut:

Tabel 1. Distribusi Frekuensi Skor Variabel Penguasaan Kosakata

\begin{tabular}{|c|c|c|c|c|c|}
\hline \multirow{2}{*}{ Kelas Interval } & \multicolumn{2}{|l|}{ batas } & \multicolumn{3}{|c|}{ Frekuensi } \\
\hline & bawah & atas & Absolut & Kumulatif & Relatif (\%) \\
\hline $20-26$ & 19,5 & 26,5 & 3 & 3 & 2.5 \\
\hline $27-33$ & 26,5 & 33,5 & 11 & 14 & 9.17 \\
\hline $34-40$ & 33,5 & 40,5 & 19 & 33 & 15.83 \\
\hline $41-47$ & 40,5 & 47,5 & 19 & 52 & 15.83 \\
\hline $48-54$ & 47,5 & 54,5 & 25 & 77 & 20.83 \\
\hline $55-61$ & 54,5 & 61,5 & 22 & 99 & 18.33 \\
\hline $62-68$ & 61,5 & 68,5 & 21 & 120 & 17.5 \\
\hline Jumlah & & & 120 & & 100 \\
\hline
\end{tabular}

Berdasarkan tabel 1 dapat di tafsirkan bahwa skor penguasaan kosakata tersebar pda beberapa kelompok kelas interval, yaitu skor dengan persentase tertinggi diperoleh pada interval 48-54 sebesar 20,83\%. Sedangkan skor terendah yaitu pada interval 20-26 dengan persentase $2,5 \%$. Sehingga dapat disimpulkan secara umum bahwa skor penguasaan kosakata kebanyakan terkumpul pada nilai kurang dari 54

Penguasaan kosakata berdasarkan tabel 1 dapat dibuat grafik histogram. Terdapat dua sumbu yang diperlukan dalam yakni sumbu vertical sebagai sumbu absolute, dan sumbu horizontal sebagai sumbu skor perolehan instrument. Adapun batas- batas kelas interval pada sumbu horizontal dimulai dari 19,5 hingga 68,5. Nilai-nilai diperoleh dengan cara mengutangkan 0,5 dari data terkecil dan menambahkan 0,5 pada setiap batas atas kelas tetinggi. Grafik histogram dari data sebaran data instrumen penguasaan kosakata dapat dilihat pada gambar: 
Gambar 1 Histogram Skor Penguasaan Kosakata

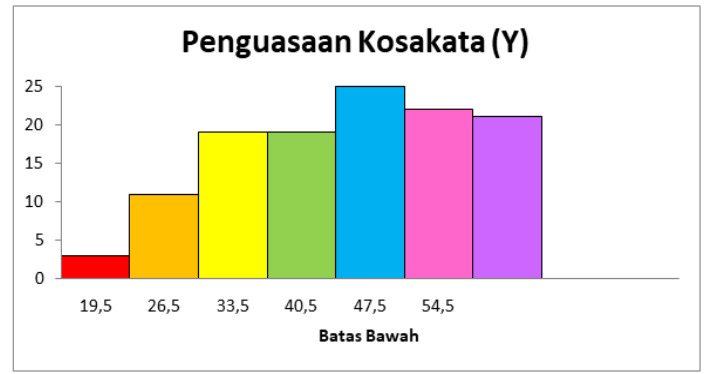

\section{B. Persepsi Dukungan Orangtua}

Pada variabel persepsi dukungan orangtua data diukur menggunakan instrumen wawancara pada anak, yang terdiri dari 18 butir pertanyaan Data yang diperoleh di lapangan kemudian diolah secara statistik. Analisis deskriptif digunakan untuk melihat gambaran data pada masing-masing variabel yang dinyatakan melalui mean, median, modus, dan simpangan baku dalam bentuk tabel dan histogram. Banyaknya kelas diperoleh 6 kelas dan panjang tiap kelas yaitu 7, dengan nilai skor maksimum 72 dan skor minimum 36 sehingga rentang skor 36.

Berdasarkan hasil perhitungan statistik deskriptif diperoleh instrumen dukungan sosial orangtua mempunyai nilai rata-rata (mean) sebesar 60,61 dengan median 61 sebesar, modus 61 sebesar, dan standar deviasi 5,65 Pengelompokan data dapat dilihat pada tabel distribusi frekuensi tersebut:

Tabel 2. Distribusi Frekuensi Skor Variabel Persepsi Dukungan Orangtua

\begin{tabular}{|l|l|l|l|l|l|}
\hline \multirow{2}{*}{ Kelas Interval } & \multicolumn{4}{|l|}{ batas } & \multicolumn{3}{l|}{ Frekuensi } \\
\cline { 2 - 6 } & bawah & atas & Absolut & Kumulatif & Relatif (\%) \\
\hline $36-42$ & 35,5 & 41,5 & 1 & 1 & 0.83 \\
\hline $43-49$ & 41,5 & 47,5 & 3 & 3 & 2.5 \\
\hline $50-56$ & 47,5 & 53,5 & 24 & 12 & 20 \\
\hline $57-63$ & 53,5 & 59,5 & 55 & 48 & 45.83 \\
\hline $64-70$ & 59,5 & 65,5 & 33 & 98 & 27.5 \\
\hline $71-77$ & 65,5 & 71,5 & 4 & 117 & 3.33 \\
\hline Jumlah & & & $\mathbf{1 2 0}$ & & $\mathbf{1 0 0}$ \\
\hline
\end{tabular}

Berdasarkan tabel 2 dapat di tafsirkan bahwa skor dukungan orangtua tersebar pda beberapa kelompok kelas interval, yaitu skor dengan persentase tertinggi diperoleh pada interval 
57-63 sebesar 45,83\%. Sedangkan skor terendah pada interval 36-42 dengan persentase 0,83\%. Sehingga dapat disimpulkan secara umum bahwa skor dukungan orangtua kebanyakan terkumpul pada nilai kurang dari 63 .

Data persepsi dukungan orangtua berdasarkan tabel 2 dapat dibuat grafik histogram. Terdapat dua sumbu yang diperlukan dalam yakni sumbu vertical sebagai sumbu absolute, dan sumbu horizontal sebagai sumbu skor perolehan instrument. Adapun batas- batas kelas interval pada sumbu horizontal dimulai dari 35,5 hingga 77,5. Nilai-nilai diperoleh dengan cara mengutangkan 0,5 dari data terkecil dan menambahkan 0,5 pada setiap batas atas kelas tetinggi. Grafik histogram dari data sebaran data instrumen dukungan sosial orangtua dapat dilihat pada gambar:

Gambar 2. Histogram Skor Persepsi Dukungan Orangtua

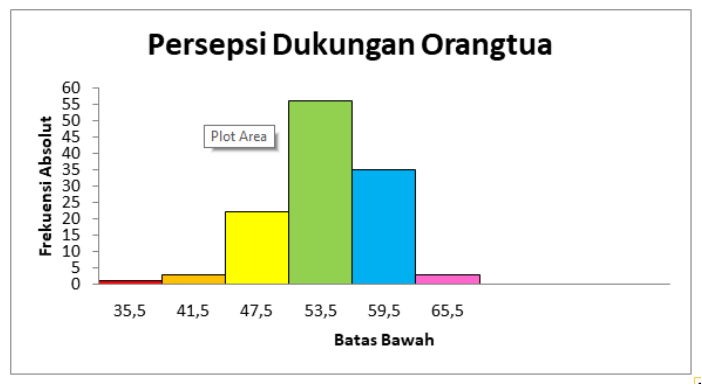

\section{Pengujian Persyaratan Analisis}

Analisis data yang digunakan pada penelitian ini menggunakan teknik korelasional. Penggunakan teknik tersebut memerlukan beberapa uji persyaratan analisis yaitu uji statistik deskriptif maupun statistik inferensial. Uji normalitas, homogenitas dan linieritas merupakan syarat dari uji statistik inferensial pada penelitian korelasional, berikut penjabarannya:

1. Uji Normalitas dan Homogenitas

Uji normalitas dari hasil perhitungan menggunakan uji Kolmogorov-Smirnov, variabel penguasaan kosakata dengan nilai Sig 0,079 $>(n=120, \alpha=0,05)$. Dengan demikian dapat dikatakan bahas semua dara variabel yang diperoleh dalam penelitian ini berasal dari populasi yang terdistrubusi secara normal. variabel persepsi dukungan orangtua dengan nila 
Sig 0,88 > $(\mathrm{n}=120, \alpha=0,05)$. Dengan demikian dapat dikatakan lebih bahwa sebaran data dukungan orangtua dari populasi berdistribusi normal.

Dalam penelitian ini uji homogenitas dilakukan dengan menggunakan Uji F dengan kriteria "apabila p-value lebih besar dari nilai pada taraf signifikansi $(\alpha)$ maka $\mathrm{H}_{0}$ diterima atau kelompok data tersebut homogen. Uji homogenitas Dukungan Orangtua Levene's Test Equality of error Variens, diperoleh $F=2,088$, df1=19; df2=94; dan p-value $=0.011>0,05$ atau $\mathrm{H}_{0}$ diterima. Dengan demikian data dukungan sosial adalah homogen.

Pengujian linieritas hubungan antara persepsi dukungan orangtua dengan penguasaan kosakata dilakukan dengan menggunakan analisis regresi linier. Dari hasil perhitungan analisis regresi sederhana berdasarkan data variabel Persepsi dukungan orangtua diperoleh harga $a=18,321$ dan $b=0,692$ dengan demikian bentuk hubungan antara kedua variabel tersebut dapat digambarkan melalui persamaan regresi $\Upsilon=18,321+0,692 \mathrm{X}_{1}$.

Tabel 3. Distribusi Frekuensi Skor Variabel Penguasaan Kosakata

\begin{tabular}{|c|c|c|c|c|c|}
\hline \multirow[b]{2}{*}{ Model } & \multicolumn{2}{|c|}{$\begin{array}{l}\text { Unstandardized } \\
\text { Coefficients }\end{array}$} & \multirow{2}{*}{\begin{tabular}{|l} 
Standardized \\
Coefficients
\end{tabular}} & \multirow[b]{2}{*}{$\mathrm{t}$} & \multirow[b]{2}{*}{ Sig. } \\
\hline & B & Std. Error & & & \\
\hline $\begin{array}{ll}1 & \text { (Constan } \\
\text { t) } \\
\text { duksos }\end{array}$ & $\begin{array}{l}18.321 \\
0,692\end{array}$ & $\begin{array}{l}1.894 \\
1.174\end{array}$ & .843 & $\begin{array}{l}9.674 \\
16.99 \\
8\end{array}$ & $\begin{array}{l}.000 \\
.000\end{array}$ \\
\hline
\end{tabular}

a. Dependent Variable: PengKK

Berdasarkan tabel 3 dapat diperoleh $t_{\text {hitung }}$ 16,998 berada dalam taraf signifikansi 0.00 . hal ini berarti terdapat hubungan linier yang kuat antara persepsi dukungan orangtua dengan penguasaan kosakata.

\section{Pengujian hipotesis}

Pada penelitian ini uji hipotesis ini menjelaskan hubungan antara persepsi dukungan orangtua, kemampuan sosial dan penguasaan kosakata. Dijelaskan sebagai berikut: 


\section{Hubungan antara Persepsi Dukungan Orangtua (X) dengan Penguasaan Kosakata}

$(\mathbf{Y})$

Hipotesis pertama diajukan dalam penelitan ini adalah terdapat hubungan positif signifikan antara hubungan antara persepsi dukungan orangtua $\left(\mathrm{X}_{1}\right)$ dengan penguasaan kosakata (Y). Proses pengujian hipotesis tersebut dapat digambarkan sebagai berikut:

$$
\begin{aligned}
& H_{0}: \rho x y_{1}=0(\alpha=0,05 ; n=120) \\
& H_{1}: \rho x y_{1}>0(\alpha=0,05 ; n=120)
\end{aligned}
$$

Tabel 4. Hubungan antara Variabel $\mathrm{X}_{1}$ dengan $\mathrm{Y}$

\begin{tabular}{|l|l|l|l|l|}
\hline Hubungan & $\mathrm{n}$ & $\mathrm{r}_{x \psi}$ & $\mathrm{r}_{\text {tabal }}$ & Kesimpulan \\
\hline Persepsi Dukungan & 120 & 0,84 & 0,149 & $\mathrm{H}_{0}=$ ditolak \\
Orangtua (X) dengan & & & $($ satu & $\mathrm{H}_{1}=$ diterima \\
Penguasaan Kosakata (Y) & & & arah) & \\
& & & $0,179(2$ & \\
& & & & \\
& & & & \\
& & &
\end{tabular}

\begin{tabular}{|c|c|c|c|c|}
\hline Hubungan & $n$ & $t_{\text {hitung }}$ & $t_{\text {tabal }}$ & Kesimpulan \\
\hline $\begin{array}{l}\text { Persepsi Dukungan } \\
\text { Orangtua }\left(\mathrm{X}_{1}\right) \text { dengan } \\
\text { Penguasaan Kosakata }(\mathrm{Y})\end{array}$ & 120 & 9,67 & 1,65 & $\begin{array}{l}\mathrm{H}_{0}=\text { ditolak } \\
\mathrm{H}_{1}=\text { diterima }\end{array}$ \\
\hline
\end{tabular}

Tabel 5. Signifikansi antara Variabel X dengan Y

Berdasarkan tabel perhitungan di atas dapat disimpulkan bahwa hipotesis nol yang menyatakan tidak terdapat hubungan yang positif signifikan antara persepsi dukungan orangtua dengan penguasaan kosakata dinyatakan ditolak. Dengan demikian penelitian ini menerima hipotesis alternatif yang menyatakan terdapat hubungan positif signifikan antara persepsi dukungan orangtua dengan penguasaan kosakata.

\section{DISKUSI}

Penelitian ini merupakan penilitian korelasional yang mengkaji hubungan variabel beas dan terikat. Variabel yang dikaji adalah persepsi dukungan orangtua (X) dengan penguasaan kosakata (Y). 
Hasil pengujian hipotesis pertama menyatakan bahwa terdapat hubungan positif persepsi dukungan orangtua (X) dengan Penguasaan Kosakata (Y). Hal tersebut dapat didukung dengan beberapa penjelasan." Johson dalam Grace mengatakan "I define "mastery" of subject matter informally as remembering and understanding - along with novice-levelability to apply the knowledge you've acquired". Uraian tersebut dapat diartikan bahwa penguasaan secara informal sebagai proses mengingat dan memahami untuk menerapkan pengetahuan yang diperolehnya”. Penguasaan kosakata secara informal diperoleh anak dari interaksi dengan orangtuanya sejak anak dilahirkan, proses yang berulang-ulang membuat anak lebih memahami dan dapat diterapkannya.

Penguasaan kosakata yang diperoleh anak didalam keluarga dan dukungan dari orangtuanya akan berperngaruh pada kehidupannya disekolah. Jalongo menjelaskan bahwa "oral vocabulary refers to words that we use in speaking or recognize in listening and reading vocabulary refers to words we recohnize or use in print. Berdasarkan pemaparan tersebut dapat diartikan bahwa, kosakata lisan mengacu pada kata-kata yang digunakan anak dalam berbicara atau memahami kata pada saat mendengarkan dan kosakata membaca mengacu pada kata-kata yang anak kenali atau pahami yang terdapat di media cetak atau buku bacaan. Anak tidak akan dapat memahami bacaan apabila orangtua tidak mendukungnya untuk mengenal kosakata baru setiap harinya. Orangtua yang membimbing atau mendukung secara berkala akan memperlihatkan anak yang memiliki penguasaan kosakata yang baik.Jelas bahwa, peguasaan kosakata anak berkembang seiring dengan pengalaman yang dimiliki anak dari hasil dukungan orangtua (ibu) yang membantu anak untuk mengembangkan kosakatanya. Semakin besar stimulus yang diberikan oleh orangtua (ibu) untuk anak, maka akan semakin besar peningkatan kosakata anak melalui kata-kata baru yang diucapkan oleh orang yang berada di sekitanya. Hal ini menunjukkan bahwa semakin tinggi dan positif persepsi dukungan orangtua maka semakin tinggi penguasaan kosakata. Begitupula sebaliknya, semakin rendah dan negative dukungan orangtua semakin rendah pula penguasaan kosakata. 


\section{SIMPULAN DAN SARAN}

\section{A. Kesimpulan}

Persepsi dukungan orang tua dan merupakan salah satu faktor terbesar yang mempengaruhi penguasaan kosakata, terdapat beberapa faktor-faktor lain yang mempengaruhi penguasaan kosakata anak yaitu faktor kesehatan, intelegensi dan sosial ekonomi keluarga dari anak itu sendiri.

\section{B. Saran}

Berdasarkan hasil peneltian, pembahasan hasil penelitian dan keterbatasan penelitian dapat kemukakan beberapa saran dalam penelitian ini sebagai berikut:

1. Bagi guru dan pendidik, sebaiknya guru lebih mengetahui perkembangan bahasa anak, sehingga guru dapat mengukur jumlah kata yang sudah dikuasai anak dan mengukur penguasaan kosakata anak. Selain itu untuk meningkatkan penguasaan kosakata anak dapat diberikan kegiatan-kegiatan yang berhubungan dengan interaksi dengan orang lain.

2. Bagi orang tua, sebaiknya orang tua lebih memperhatikan interaksi dengan anak dalam kesehariannya. Orang tua dengan mengajak berinteraksi dengan anak dalam kesehariannya dapat menstimulasi pembendaharaan kata dan mengembangkan penguasaan kosakata anak sesuai dengan tahapan usianya.

3. Bagi peneliti selanjutnya, hendaknya melakukan penelitian lebih lanjut dan mengembangkan dengan menambahkan beberapa variabel lain yang sekiranya berhubungan dengan penguasaan kosakata anak. Penelitian selanjutnya juga dapat mempeluas area penelitian supaya data yang diperoleh akan dapat lebih mendekati kondisi yang sebenarnya. 


\section{DAFTAR PUSTAKA}

Ahmad Santoso. (2011). Perkembangan Anak Usia DIni Pengantar dalam Berbagai Aspeknya . Jakarta: Kencana.

Chirstoper R. Martell.at.al. (2010). Behavioral Activation for Depression (New York; Guilford)

Encylopedia on Early Childhood Development. (2009). Parents' Role in Fostering Young Children's Learning and Language Development, diunduh pada tanggal 29 September: Pukul 18.46 WIB

Geraldine French, Aistear. (2007). Creatchuraclam na Luath- Oige The Early Chidhood Curriculum Framework, Chidren's early learning and development. NCCA. diunduh pada tanggal 22 Juli 2016, pukul 15.14 WIB

Grace, A working Definition of Mastery, (http://educationquicktakes.com/2011 /05/workingdefinition-of-masteryh.tml) diakses 11 juli 2016 pukul 20.02

Handini, Myrnawaty Crie. (2012). Metodologi Penelitian untuk Pemula, Jakarta: FIP Press

Jalongo. (2014). Early Childhood Language Art. USA: PEARSON EDUCATION.

Lin-Huey Shyan. (2009). Relationship of Job Stress, Social Support, and Depretion in ICU Nurse (United State; ProQuest LLC)

Otto, Beverly. (2010). Language Development in Early Childhood, Third Edition (Columbus: Pearson)

Ridwan. (2010). Metode dan Teknik Menyussn Tesis. Bandung: Alfabeta

Santoso, Ahmad. (2011). Perkembangan Anak Usia DIni Pengantar dalam Berbagai Aspeknya (Jakarta: Kencana, )

Selley E Taylor. (2009). Health Psychology, Seventh Edition,( New York; McGraw-Hill)

Sue Roulstone, James Law, Robert Rush, Judy Clegg, Tim Peters. (2010). JURNAL UK government, Department, investigating the role of Language in children's early educational outcomes, Research Report DFE-RR134, diunduh pada tanggal 25 September 2016; pukul 17:43 WIB 
Psikologi Prima

Vol 3, No 2 November 2020 e-ISSN : 2598 - 8026

Sugiyono. (2012). Metode Penelitian Pendidikan, Pendekatan Kuantitatif, Kualitatif, dan R\&D. Bandung: Alfabeta. 